\title{
Simulation of the regularities of physical exercises learning process of boys aged 8 years old
}

\author{
Ivashchenko O.V. ${ }^{\mathrm{ABCDE}}$, Iermakov S.S. ${ }^{2 \mathrm{ABCDE}}$, Khudolii O.M. ${ }^{\mathrm{ABCDE}}$, Yermakova T.S. ${ }^{3 \mathrm{ADE}}$, \\ Cieślicka M. ${ }^{4 \mathrm{ADE}}$, Harkusha S.V. ${ }^{5 \mathrm{ADE}}$ \\ ${ }^{1}$ H.S. Skovoroda Kharkiv National Pedagogical University, Ukraine \\ ${ }^{2}$ Department of Tourism and Recreation, Gdansk University of Physical Education and Sport, Poland \\ ${ }^{3}$ Kharkiv State Design and Art Academy, Ukraine \\ ${ }^{4}$ Kazimierz Wielki University in Bydgoszcz, Poland \\ ${ }^{5}$ T.H. Shevchenko National University «Chernihiv Colehium», Ukraine
}

Authors' Contribution:

A - Study design; B - Data collection; C - Statistical analysis; D - Manuscript Preparation; E - Funds Collection.

\begin{abstract}
Purpose: $\quad$ to determine the peculiarities of the formation of motor skills in boys aged 8 years

Material: $\quad$ In study participated boys of eight years old $(n=48)$. The study used factor experiment plans. The purpose of this experiment was to optimize the modes of education and to determine the peculiarities of the formation of motor skills in boys.

Results: $\quad$ Discriminant analysis allowed: to determine the modes of exercise in the formation of motor skills; to answer the question as to how significantly different modes of work on the effectiveness of the formation of motor skills. Established: which of the variables most significantly affect the differentiation of classes; to which class the object belongs based on the values discriminant variables. The influence of the number of approaches, the number of repetitions in the approach and the interval of rest on the level of training for movements is revealed.

Conclusions: $\quad$ To choose the most rational mode of exercising in the process of forming motor skills can be used the first discriminating function with an emphasis on the most informative variables.

Keywords: discriminant function, classification, simulation, learning process, boys.
\end{abstract}

\section{Introduction}

One of the problems of school physical education is the optimization of the educational process of schoolchildren. Available studies reveal:

- content of the subject physical education and levels of its study at school [1];

- the impact of training load on the effectiveness of education and the health of schoolchildren [2];

- the role of motor activity in the development of school-age children [3];

- methodology for determining the state of development of motor function in children and adolescents [4, 5].

The optimization of the process of learning physical exercises of schoolchildren is revealed in the following works: the influence of modes of exercising on the formation of motor skills $[6,7]$; the effectiveness of the use of the methods of programmed education at the lessons of physical culture in school [8]; the effectiveness of using network planning for passing the training material $[9,10]$; building learning process based on information models $[11,12]$; conditions for the formation of the motor function $[13,14]$.

The task of physical education of school-age children is the teaching of motor activity and the development of motor abilities $[12,15]$. The process of study is considered from the positions: organizations $[6,16]$, motivation for motor activity (the higher the level of training exercises

(c) Ivashchenko O.V., lermakov S.S., Khudolii O.M., Yermakova

T.S., Cieślicka M., Harkusha S.V., 2018

doi:10.15561/18189172.2018.0102 the greater the volume of motor activity) [17, 18]; relationships between learning outcomes and motor activity are studied (learning success induces an increase in motor activity) [2, 19]; cognitive and motor learning $[20,21]$; teacher's readiness to study; the formation of moral values in the process of motor skills' formation [22]; the impact of motor readiness on the effectiveness of learning [7]; the effect of physical activity on learning effectiveness [23].

In previously published works it was found that the level of motor readiness of schoolchildren affects the ratio of learning processes and the development of motor abilities [24, 25]. The development of motor abilities is effective if they become part of the acquired motor skills. It has been established that the learning efficiency increases if the algorithmic instruction method is used $[9,10]$ and takes into account the modes of alternating exercise and rest [9]; O.V. Ivashchenko [6]. One of the methods for studying the peculiarities of motor skills in children and adolescents is simulation.

Recent publications have found that simulation is an effective method for obtaining new information about the possibility of conducting current and final control based on testing motor development of children and adolescents $[26,27]$. One of the methods of statistical simulation is a discriminant analysis. The effectiveness of its use in the classification of the state of functional and motor fitness of children and adolescents indicate the data of scientific literature [26, 28]. 
Thus, the study of the peculiarities of the formation of motor skills in junior school pupils is relevant.

The purpose of the study is to determine the peculiarities of the formation of motor skills in boys aged 8 years.

\section{Material and methods}

Participators. The study involved boys aged 8 years old $(\mathrm{n}=48)$.

Organization of research. In the process of staging the research were used conceptual approaches to planning an experiment in the study of the effectiveness of the learning process and the development of training models $[6,26]$.

The study used the plans of a factor experiment PFE $2^{3}$ (Table 1). The purpose of PFE was to optimize the training regimens and to determine the peculiarities of the formation of motor skills in boys of 8 years.

In the pedagogical experiment was studied the influence of the number of approaches $\left(x_{1}\right)$, the number of repetitions in the approach $\left(x_{2}\right)$ and the intervals of rest $\left(x_{3}\right)$ on the level of training of gymnastic exercises of 8 years old boys.

In the process of teaching gymnastic exercises in each class, the level of training was evaluated by an alternative method ("fulfilled", "failed"), the probability of exercise was calculated $(p=n / m$, where $n-$ is a number of successful attempts, $\mathrm{m}$ - is a total number of attempts).

The method of algorithmic instructions was used in teaching children of elementary school age $[6,9,10]$. The training of the forward roll was conducted with boys of 8 years old.

Statistical analysis. Materials of the study were developed in the program of statistical analysis - IBM SPSS 20. In the process of discriminant analysis, a prognostic model for membership in the group was created. This model builds a discriminant function (or, when groups are more than two, a set of discriminant functions) in the form of a linear combination of predictor variables that provides the best division of groups. These functions are built on a set of observations for which is known their belonging to groups. These functions can be applied to the new observations with known values of predictor variables and unknown group belonging.

For each canonical discriminant function, the actual value, the percentage of dispersion, canonical correlation, Wilks' Lambda, $\chi$-square (Chi-square) are calculated.

A discriminatory analysis was conducted to determine the effect of the proposed modes of exercise on 8 years old boys. It was analyzed the influence of the number of approaches, the number of repetitions in the approach and the interval of rest on the level of learning according to the following movements:

1. From position sitting on floor roll back in tuck and turn in initial position;

2. From squat position with hands on floor roll back in tuck and turn in initial position;

3. From standing position with hands on floor, legs are expanded, make forward roll in sitting position with expanded legs;

4. From standing position with hands on floor make forward roll in sitting position in tuck;

5. From standing position with hands on floor make forward roll in sitting position with hands on floor.

\section{Results}

The first canonical function explains the variation of results by $83.5 \%$, which indicates its high informativity $(\mathrm{r}=0,862)$ (Table 2). Materials of the analysis of canonical functions indicate the statistical significance of the first canonical function $(\lambda=0,216 ; p=0,001)$. The first function has a high discriminant ability and meaning in the interpretation of the general population (Table 3).

The structural coefficients of discriminant functions are coefficients of the correlation of variables with a function. They indicate that the functions are significantly related to the level of training of pedicle exercises forward. The level of training of exercises depends on the modes of training, and the level of training caviar forward from the level of training appended exercises (Table 4).

Graphic material (Figure 1) shows the density of

Table 1. Matrix of the factor experiment of type 23 in the study of influence of different modes of repetition exercises on their level of training

\section{Factors}

\begin{tabular}{llll} 
Experimental groups & $\begin{array}{l}x_{1} \\
\text { number of approaches } \\
\text { (times) }\end{array}$ & $\begin{array}{l}x_{2} \\
\text { number of repetitions in } \\
\text { approaches (times) }\end{array}$ & $\begin{array}{l}x_{3} \\
\text { interval of rest (c) }\end{array}$ \\
\hline 1 & 6 & 1 & 60 \\
2 & 12 & 1 & 60 \\
3 & 6 & 3 & 60 \\
4 & 12 & 3 & 60 \\
5 & 6 & 1 & 180 \\
6 & 12 & 1 & 180 \\
7 & 6 & 3 & 180 \\
8 & 12 & 3 & 180 \\
\hline
\end{tabular}


Table 2. Canonical discriminant function. Own values. Boys aged 8 years old

\begin{tabular}{lllll}
\hline Function & Own values & $\begin{array}{l}\text { \% explained } \\
\text { variance }\end{array}$ & Cumulative \% & Canonic correlation \\
\hline 1 & 2,140 & 83,5 & 83,5 &, 826 \\
2 &, 241 & 9,4 & 92,9 &, 441 \\
3 &, 151 & 5,9 & 98,8 &, 362 \\
4 &, 030 & 1,2 & 100,0 &, 170 \\
\hline
\end{tabular}

Table 3. Canonical discriminant function. Wilks' Lambda. Boys aged 8 years old

\begin{tabular}{lllll}
\hline Control of functions & Wilks' Lambda & Chi-square & $\begin{array}{l}\text { Degree of } \\
\text { freedom }\end{array}$ & $\mathbf{p}$ \\
\hline from 1 to 4 &, 216 & 74,996 & 28 &, 000 \\
from 2 to 4 &, 680 & 18,933 & 18 &, 396 \\
from 3 to 4 &, 844 & 8,334 & 10 &, 596 \\
4 &, 971 & 1,435 & 4 &, 838 \\
\hline
\end{tabular}

Table 4. Structural coefficients of canonical discriminant function. Boys aged 8 years old

\begin{tabular}{|c|c|c|c|c|}
\hline \multirow{2}{*}{ Content } & \multicolumn{4}{|c|}{ Function } \\
\hline & 1 & 2 & 3 & 4 \\
\hline $\begin{array}{l}\text { From standing position with hands on floor make forward roll in } \\
\text { sitting position in tuck }\end{array}$ & ,505 &,$- 740 *$ &,- 187 & 403 \\
\hline $\begin{array}{l}\text { From position sitting on floor roll back in tuck and turn in initial } \\
\text { position }\end{array}$ & ,393 & ,054 & ,913* &,- 097 \\
\hline $\begin{array}{l}\text { From squat position with hands on floor roll back in tuck and turn in } \\
\text { initial position }\end{array}$ & ,326 & 473 &,- 138 & ,807* \\
\hline $\begin{array}{l}\text { From standing position with hands on floor, legs are expanded, make } \\
\text { forward roll in sitting position with expanded legs }\end{array}$ & ,492 & ,453 &,- 515 &,$- 536^{*}$ \\
\hline
\end{tabular}

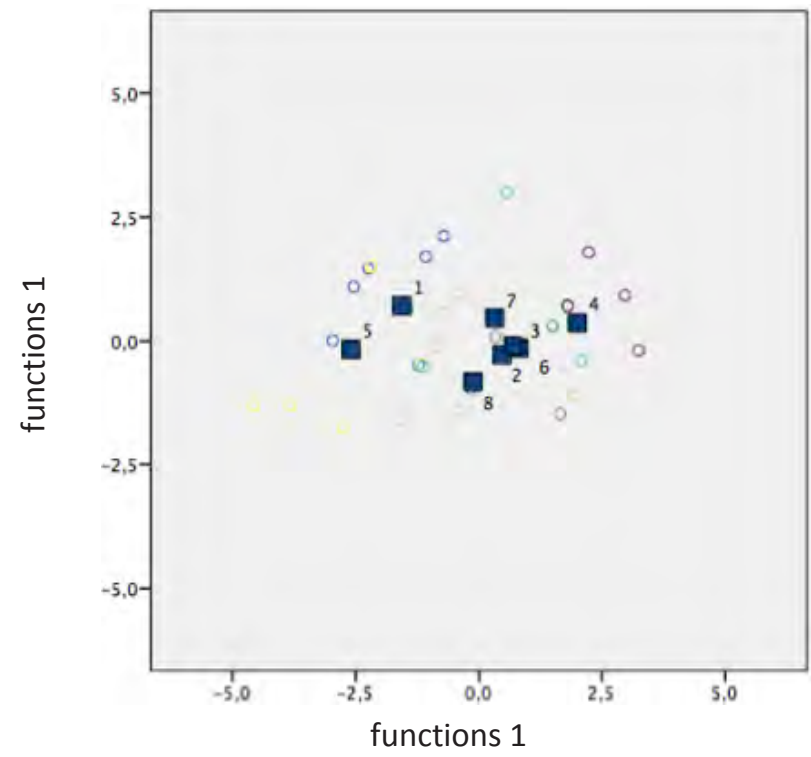

Fig. 1. Canonical discriminatory functions. Graphic representation of the results of the classification of the level of exercise execution of boys aged 8 years: - - centroids for data groups after 1-8 variants of exercise modes

objects in each class and the distinct boundary between classes. This material points to the ability to choose the mode of exercise for successful training of the simmer forwards.
To select a variant of the mode of execution of the forward roll into the equation of discriminant function we will substitute the level of training of each exercise, which provides a positive effect of learning: 
$\mathrm{Y}=-8,553+3,507 \mathrm{X}_{1}+1,296 \mathrm{X}_{2}+4,455 \mathrm{X}_{3}+4,007 \mathrm{X}_{4}$, $\mathrm{Y}=-8,553+3,507 \times 0,75+1,296 \times 0,75+4,455 \times 0,75+$ $4,007 \times 0,75=1,395$,

where $\mathrm{Y}$ is the result of the function, $\mathrm{X}_{1}$ - the level of training of exercise $1, X_{2}$ - the level of training of exercise $2, X_{3}$ - the level of training of exercise $3, X_{4}$ the level of training of exercise 4 .

The obtained result is compared with the values of centroids for the first canonical function (Table 5). The comparison indicates that the most favorable conditions for the training of the forward roll in boys of 8 years are created as a result of the use of the fourth mode of work.

\section{Discussion}

Scientific literature describes the use of discriminatory analysis for classifying the state of preparedness of children and adolescents. Gert-Jan de Bruijn and Benjamin Gardner [29] used discriminant function and dispersion analysis to study the effect of different levels of motivation on the increase in motor activity of young people. Dorita Du Toit et al. [30] through discriminant analysis, studied the relationship between physical fitness and academic achievement at children aged 9-12 years. The boys and girls were classified by level of physical preparedness, motor activity and educational achievements. The positive correlation between components of physical preparedness and academic achievements was revealed by more significant correlations: among girls than boys; among older boys and girls. Lulzim I. [31], with the help of canonical discriminant analysis, found out: is there any change in the morphological and motor performance of girls under the influence of sports. The morphological characteristics (longitudinal circular proportions, proportions of body measurements and proportions of adipose tissue), level of development of motor abilities (explosive force, speed of sprint run and speed of stable run) were analyzed. The result of this study shows that girls (who were actively engaged in sports) had statistically significant differences in all morphological and motor variables in comparison with other girls (who were not active in sports). Geoffrey D. Broadhead and Gabie E. Church [32]: discriminant analysis was used to classify physical education for children with special needs.

In previous studies, we observed a high discriminant and predictive ability of the functions received: in assessing the motor preparedness of children and adolescents [33, 34]; in the classification of strength loads among schoolchildren of junior grades $[35,36]$; in the classification of motor readiness, taking into account the level of training [24, 37].

The obtained data allowed to establish the effectiveness of discriminant analysis in the classification of modes of exercise physical exercise in the formation of motor skills in junior schoolchildren. In the process of analysis, the canonical coefficients of discriminant function (nonstandardized) are calculated, which act as factors of the given values of the variables of a discriminant function. On the basis of them it is possible to classify the modes of exercising on the level of training of physical exercises boys aged 8 years, which has practical value.

Consequently, discriminatory analysis allowed to answer the question: how reliable is it possible to classify the modes of exercise; as the level of training of a series of educational tasks affects the assimilation of the exercise as a whole.

\section{Conclusions}

Discriminant analysis allowed to determine: the modes of exercise in the process of forming motor skills; to answer the question as to how significantly different modes of work on the effectiveness of the formation of motor skills; which motor tasks most significantly affect the differentiation of classes; to which class the object belongs to based on the values of discriminant variables.

For the choice of the most rational mode of exercises in the process of developing motor skills in 8 years old boys, the first discriminant function can be used with an emphasis on the most informative variables.

The prospect of further exploration is the study of methodological approaches to pedagogical control of the process of teaching physical exercises of schoolchildren of junior school age.

\section{Conflict of interests}

The authors declare that there is no conflict of interests.

Table 5. Functions in centroid groups. Boys 8 years old

\begin{tabular}{lllll}
\hline Variant of work's regime & Function & & & \\
& $\mathbf{1}$ & $\mathbf{2}$ & $\mathbf{3}$ & $\mathbf{4}$ \\
\hline 1,00 & $-1,563$ &, 703 &, 075 &,- 171 \\
2,00 &, 462 &,- 284 &,- 116 &,- 117 \\
3,00 &, 813 &,- 145 &,- 558 &, 218 \\
4,00 & 2,005 &, 362 &,- 209 &,- 183 \\
5,00 & $-2,597$ &,- 171 &,- 330 &, 055 \\
6,00 &, 689 &,- 100 &, 100 &, 038 \\
7,00 &, 316 &, 460 &, 560 &, 257 \\
8,00 &,- 125 &,- 824 &, 479 &,- 097 \\
\hline
\end{tabular}




\section{References}

1. Ekberg JE. What knowledge appears as valid in the subject of Physical Education and Health? A study of the subject on three levels in year 9 in Sweden. Physical Education and Sport Pedagogy, 2016; 21(3), 249-267. https://doi.org/10.1 080/17408989.2014.946006

2. Lang C, Feldmeth AK, Brand S, Holsboer-Trachsler E, Pühse $\mathrm{U}$, Gerber M. Effects of a physical education-based coping training on adolescents' coping skills, stress perceptions and quality of sleep. Physical Education and Sport Pedagogy, 2017;22(3):213-230. https://doi.org/10.1080/17408989.201 6.1176130

3. Krucevich TYu, Bezverkhnia HV. Recreation in the physical culture of different population groups: teaching. Kiev: Olympic Literature; 2010. (in Ukrainian)

4. Ivashchenko O, Khudolii O, Iermakov S, Harkusha S. Physical exercises' mastering level in classification of motor preparedness of 11-13 years old boys. Journal of Physical Education and Sport, 2017;17(3):1031-1036. https://doi. org/10.7752/jpes.2017.03158

5. Lopatiev A, Ivashchenko O, Khudolii O, Pjanylo Y, Chernenko S, Yermakova T. Systemic approach and mathematical modeling in physical education and sports. Journal of Physical Education and Sport, 2017;17:146-155. https://doi.org/10.7752/jpes.2017.s1023

6. Ivashchenko OV. Modelling of physical education students. Kharkiv: OVS; 2016. (in Ukrainian)

7. Ivashchenko OV. Theoretical and methodological bases of modeling of learning process and development of motor abilities in children. Dokt. Diss. Chernigov; 2017. (in Ukrainian)

8. Miroshnychenko DT. Method of teaching acrobatic exercises of junior pupils. Teoriâ ta Metodika Fizičnogo Vihovannâ, 2007; 0(12): 29-31.

9. Khudolii OM. Basics of the methodology of teaching gymnastics, Kharkiv: OVS;. 2008. (in Ukrainian)

10.Khudolii OM. General Fundamentals of Theory and Methodology of Physical Education, Kharkiv: OVS; 2008. (in Ukrainian)

11.Khudolii OM, Iermakov SS. Regularities of the learning process of young gymnasts. Teoriâ ta Metodika Fizičnogo Vihovannâ, 2011; 0(5); 3-18, 35-41. https://doi.org/ tmfv.2011.5.707 (in Ukrainian)

12.Khudolii OM, Ivashchenko OV, Chernenko SO. Simulation of junior schoolchildren's training to acrobatic exercises and vaults. Pedagogics, psychology, medical-biological problems of physical training and sports, 2015; 19(7): 64-71. https:// doi.org/10.15561/18189172.2015.0709

13. Nosko MO. Problems of training and improvement of human motor function. Pedagogics, psychology, medical-biological problems of physical training and sports, 2001; 5: 18-25. (in Ukrainian)

14.Nosko MO, Kryvenko AP, Manievych OR. Formation of motor skills in physical education and sports. Pedagogics, psychology, medical-biological problems of physical training and sports, 2001; 8: 7-9.

15.Arziutov G, Iermakov S, Bartik P, Nosko M, Cynarski WJ. The use of didactic laws in the teaching of the physical elements involved in judo techniques. Ido Movement for Culture, 2016;16(4):21-30. https://doi.org/10.14589/ ido.16.4.4

16.Krucevich T, Trachuk S, Napadij A. Planning of physical culture training process for secondary comprehensive schools' pupils. Teoriia i metodika fizichnogo vikhovannia $i$ sportu, 2016; 1: 36-42. (in Ukrainian)
17.Darnis F, Lafont L. Cooperative learning and dyadic interactions: two modes of knowledge construction in socioconstructivist settings for team-sport teaching. Physical Education and Sport Pedagogy, 2015;20(5):459-473. https:// doi.org/10.1080/17408989.2013.803528

18.Xu X, Ke F. From psychomotor to 'motorpsycho': Learning through gestures with body sensory technologies. Educational Technology Research and Development, 2014; 62(6): 711-741. https://doi.org/10.1007/s11423-014-9351-8

19.Baset AR, Kozina ZL, Bazilyuk TA, Ilnickaya AS. Methodic of senior pupils' training to throwing movements on the bases of technology of complex impact on motor and intellectual development. Pedagogics, psychology, medical-biological problems of physical training and sports, 2015;19(11):3-10. https://doi.org/10.15561/18189172.2015.1101

20.Chatzipanteli A, Digelidis N, Karatzoglidis C, Dean R. A tactical-game approach and enhancement of metacognitive behaviour in elementary school students. Physical Education and Sport Pedagogy, 2016;21(2):169-184. https://doi.org/10. 1080/17408989.2014.931366

21.Altunsöz IH, Goodway JD. SKIPing to motor competence: the influence of project successful kinesthetic instruction for preschoolers on motor competence of disadvantaged preschoolers. Physical Education and Sport Pedagogy, 2016;21(4):366-385. https://doi.org/10.1080/17408989.201 5.1017453

22.Koh KT, Ong SW, Camire M. Implementation of a values training program in physical education and sport: perspectives from teachers, coaches, students, and athletes. Physical Education and Sport Pedagogy, 2016;21(3):295312. https://doi.org/10.1080/17408989.2014.990369

23.Ivashchenko OV, Kapkan OO. Simulation of process of 1415 years old girls' training of light athletic and gymnastic exercises. Pedagogics, psychology, medical-biological problems of physical training and sports, 2015; 19(8): 32-39. https://doi.org/10.15561/18189172.2015.0805

24.Ivashchenko OV. Classification of 11-13 yrs girls' motor fitness, considering level of physical exercises' mastering. Pedagogics, psychology, medical-biological problems of physical training and sports, 2017; 21(2): 65-70. https://doi. org/10.15561/18189172.2017.0203

25.Ivashchenko OV. Special aspects of motor abilities development in 6-10 years' age girls. Pedagogics, psychology, medical-biological problems of physical training and sports, 2017; 21(3): 105-110. https://doi. org/10.15561/18189172.2017.0302

26.Khudolii OM, Ivashchenko OV. Simulation of the learning process and development of motor abilities in children and adolescents, Kharkiv: OVS; 2014. (in Ukrainian)

27.Khudolii OM, Ivashchenko O. Information support learning and development of motor abilities of children and adolescents (for example, gymnastics). Teorîa ta Metodika Fìzičnogo Vihovannâ, 2013; 0(4): 3-18. https://doi. org/10.17309/tmfv.2013.4.1031 (in Ukrainian)

28.Milić M, Milavić B, Grgantov Z. Relations between sport involvement, selfesteem, sport motivation and types of computer usage in adolescents. In: S. Simović (Ed.), Proceedings of $3 \mathrm{rd}$ International Scientific Congress "Anthropological Aspects of Sport, Physical Education and Recreation”. November 2011. Banja Luka: University of Banja Luka, Faculty of Physical Education and Sport. 2011. P. 25-32.

29.Gert-Jan de Bruijn, Benjamin Gardner. Active Commuting and Habit Strength: An Interactive and Discriminant Analyses Approach. American Journal of Health Promotion, 2011;25(3): e27-e36. https://doi.org/10.4278/ajhp.090521- 


\section{QUAN-170}

30.Dorita DU TOIT, Anita E PIENAAR, Leani TRUTER. Relationship between physical fitness and academic performance in south african children. SAJR SPER, 2011;33(3): 23-35.

31.Lulzim I. Discriminant analysis of morphologic and motor parameters of athlete and non athlete girl pupils of primary school on age 14 to 15 years. $R I K(2012), 2013 ; 40(2)$ : 185 190.

32.Geoffrey D. Broadhead, Gabie E. Church Discriminant analysis of gross and fine motor proficiency data. Perceptual and Motor Skills, 1982; 55: 547-552. https://doi.org/ 10.2466/ pms.1982.55.2.547

33.Ivashchenko O, Khudolii O, Iermakov S, Lochbaum MR, Cieslicka M, Zukow W, et al. Intra-group factorial model as the basis of pedagogical control over motor and functional fitness dynamic of 14-16 years old girls. Journal of Physical Education and Sport, 2016;16(4):1190-1201. https://doi. org/10.7752/jpes.2016.04190
34.Khudolii OM, Iermakov SS, Prusik K. Classification of motor fitness of 7-9 years old boys. Journal of Physical Education and Sport, 2015;15(2), 245-253. https://doi.org/10.7752/ jpes. 2015.02038

35.Cieślicka M, Ivashchenko O. Features of formation of the cumulative effect of power loads in boys 7 years old. Journal of Education, Health and Sport, 2017; 7(1): 198-208. https:// doi.org/10.5281/zenodo.250599

36.Ivashchenko $\mathrm{O}$, Cieślicka M. Features of evaluations of power loadsin boys 7 years old. Journal of Education, Health and Sport, 2017; 7(1), 175-183. https://doi.org/10.5281/ zenodo. 249184

37.Ivashchenko O, Khudolii O, Iermakov S, Lochbaum M, Cieślicka M, Zukow W, et al. Methodological approaches to pedagogical control of the functional and motor fitness of the girls from 7-9 grades. Journal of Physical Education and Sport, 2017;17(1):254-261. https://doi.org/10.7752/ jpes. 2017.01038

\section{Information about the authors:}

Ivashchenko O.V.; http://orcid.org/0000-0002-2708-5636; tmfv@tmfv.com.ua; H.S. Skovoroda Kharkiv National Pedagogical University; Alchevskyh str. 29, Kharkiv, 61002, Ukraine.

lermakov S.S.; http://orcid.org/0000-0002-5039-4517; sportart@gmail.com; Gdansk University of Physical Education and Sport; Kazimierza Gorskiego 1, 80-336 Gdansk, Poland.

Khudolii O.M. (Corresponding author); http://orcid.org/ 0000-0002-5605-9939; tmfv@tmfv.com.ua; H.S. Skovoroda Kharkiv National Pedagogical University; Alchevskyh str. 29, Kharkiv, 61002, Ukraine.

Yermakova T.S.; http://orcid.org/0000-0002-3081-0229; yermakova2015@gmail.com; Kharkiv State Design and Art Academy; 8, Arts st., Kharkiv, 61002, Ukraine.

Cieślicka M.; http://orcid.org/0000-0002-0407-2592; cudaki@op.pl; Kazimierz Wielki University in Bydgoszcz; Chodkiewicza str. 30, 85-064 Bydgoszcz, Poland.

Harkusha S.V.; http://orcid.org/0000-0002-7120-1446; biomex@ukr.net; T.H. Shevchenko National University «Chernihiv Colehium»; Hetmana Polubotka str. 53, Chernihiv, 14013, Ukraine.

Cite this article as: Ivashchenko OV, Iermakov SS, Khudolii OM, Yermakova TS, Cieślicka M, Harkusha SV. Simulation of the regularities of physical exercises learning process of boys aged 8 years old. Pedagogics, psychology, medical-biological problems of physical training and sports, 2018;22(1):11-16. doi:10.15561/18189172.2018.0102

The electronic version of this article is the complete one and can be found online at: http://www.sportpedagogy.org.ua/index.php/PPS/issue/archive

This is an Open Access article distributed under the terms of the Creative Commons Attribution License, which permits unrestricted use, distribution, and reproduction in any medium, provided the original work is properly cited (http://creativecommons.org/licenses/by/4.0/deed.en).

Received: 11.12.2017

Accepted: 30.12.2017; Published: 26.02.2018 